\title{
Immunohistochemical expression of Ki67, EGFR and TRKC and their correlation with prognostic factors in medulloblastoma
}

\author{
A expressão imuno-histoquímica de Ki67, EGFR E TRKC e sua correlação com fatores \\ prognósticos em meduloblastomas
}

\author{
Ana Cristina Lira Sobrall'; Victor Moreschi Neto²; Gabriela Traiano ${ }^{3}$; Jeana Rosales ${ }^{3}$ \\ Luana E. Harada ${ }^{3}$; Ana Paula Percicote ${ }^{4}$; Elizabeth Schneider Gugelmin' ${ }^{5}$ Lúcia de Noronha ${ }^{6}$
}

\begin{abstract}
Introduction: Medulloblastoma is a malignant embryonal tumor of the cerebellum with poor prognosis. The treatment is based only on clinical criteria, such as risk group that only considers age, extent of tumor resection, recurrence, and metastasis. Objective: To evaluate a possible relationship between the immunoexpression of biomarkers (Ki67, receptor neutrophin-3 [TRKC], epidermal growth factor receptor [EGFR], B-cell lymphoma 2 [Bcl-2], and cyclin-D1), and the classical clinical prognostic factors of medulloblastoma. Material and method: thirty-five samples of pediatric medulloblastoma free of neoadjuvant chemotherapy were separated and reviewed for their histopathological classification; two areas representative of tumor were used in the construction of tissue microarrays. The following clinical data from 29 patients were used for comparison with the biomarkers expression: patient's age, presence or absence of complete tumor resection, staging patient's risk group, presence or absence of metastases, presence or absence of postoperative chemotherapy, and presence or absence of recurrence. Clinical follow-up of the study ranged from two to thirteen years, and cases with fatal outcome were also analyzed. Results: Patients with upper age showed higher expression of TRKC $(\phi=0.033)$. There was inversely proportional and statistically significant correlation between TRKC and Ki67 $(p=0.027)$. There was no statistical significance in the analysis of EGFR, Bcl2, and cyclin-D1. Conclusion: The immunoexpression of TRKC might be considered a biomarker related to tumors with better prognosis in patients with medulloblastoma, contributing to better risk groups' stratification.
\end{abstract}

Key words: medulloblastoma; TRKC; Ki67; EGFR; prognosis; biological behavior.

\section{INTRODUCTION}

Medulloblastoma is the most common malignant tumor of the nervous system in childhood. It is an invasive embryonal tumor of the cerebellum with tendency to metastasis by subarachnoid space ${ }^{(13)}$. It shows a neuroepithelial histological pattern from the cerebellum, consisting of small-round-cells, with hyperchromatic nuclei, immersed in delicate fibrillary matrix (neuropil). Furthermore, medulloblastoma represents $20 \%$ of intracranial tumors in children, and its peak incidence occurs around 8 years of age, and only $30 \%$ of cases occur in adults ${ }^{(12)}$.
The prognostic factors already established for cervical cancer are: (1) age of patient at diagnosis; (2) the presence of residual tumor postoperatively; and (3) presence of metastasis. These three factors divide the medulloblastoma patients in at high or low risk. Patients at high risk, usually, are those under three years of age at diagnosis, and/or with metastasis, and/or presence of residual tumor postoperatively, and generally low five-years survival rate ${ }^{(8,12)}$. Patients upper than 3 years of age at diagnosis, without residual tumor after surgery, and without metastasis, are at low risk and therefore tend to have better fiveyear survival rate re, $^{(2,13)}$.

First submission on 22/01/14; last submission on 16/06/14; accepted for publication on 16/06/14; published on 20/08/14

1. MSc of Health Sciences-School of Medicine of Pontifícia Universidade Católica do Paraná (PUC-PR); professor of Pathology at School of Medicine-PUC-PR.

2. Resident Doctor at Hospital Nossa Senhora das Graças, Curitiba-PR.

3. Resident Doctor at School of Medicine-PUC-PR.

4. PhD student in Pahology, Universidade Federal do Paraná (UFPR), assistant professor, UFPR.

5. PhD in Pathology-UFPR; head of Anatomical Pathology Service at Hospital Infantil Pequeno Príncipe

6. PhD in Pathology-UFPR; full professor of the postgraduate course in Health Sciences-PUC-PR. 
The classification of embryonal tumors based only in clinical and histopathological criteria tends to be limited. However, with the advancement of molecular techniques, the discovery of genetic protein disorders has bringing on new therapeutic and prognostic perspectives in several pediatric tumors. However, the molecular knowledge in medulloblastoma are still scarce, and studies based on molecular analysis, gene expression, and protein expression may provide valuable information that would help in understanding of the pathogenesis of these lesions, in choosing the therapeutic targets, and in the best prognostic stratification in risk groups. Thus, the stratification of this neoplasia in at-risk groups would include biomarkers identification as gene and/or protein modifications, which sometimes may be due to a more aggressive subtype $^{(3,13)}$.

Several studies conducted with groups of children's tumor, also of embryonal origin, are also using new biomarkers of cellular growth and differentiation, which better stratify these tumors in more accurate prognostic groups, in order to implement more aggressive therapies in the groups that really need it. There are several biomarkers involved in pathways of cellular growth and differentiation that are still under study and appear to have promising results in understanding the biology of medulloblastoma and in its stratification in more reliable prognostic groups, including specially neutrophins and growth factors such as tropomyosin receptor kinase (TRK) and epidermal growth factor receptor (EGFR), pro-apoptotic and anti-apoptotic proteins (B-cell lymphoma 2 [Bcl-2]) and proliferative proteins (Cyclin-D1) ${ }^{(3-6,15)}$.

\section{OBJECTIVE}

The search for new biomarkers useful in routine diagnosis, prognosis, or in the therapy of this neoplasia motivated this study to observe the immunohistochemical expression of Ki67, receptor neurotrophin-3 (TRKC), EGFR, Bcl-2, and ciclina-D1 biomarkers in medulloblastoma, and to evaluate the relationship of these biomarkers with the clinicopathological variables with prognostic value (age, presence of residual tumor, presence of metastases, and risk group).

\section{MATERIAL AND METHOD}

In this study, 35 samples of pediatric medulloblastoma from Anatomical Pathology Service at Hospital Infantil Pequeno Príncipe diagnosed during the period 1998-2009 were used. The study was approved by the Research Ethics Committee of the Hospital Infantil Pequeno Príncipe (CEP 0519-07 of November, $26^{\text {th }} 2007$ Resolution 196/96).

The review of histological slides was performed with hematoxylin-eosin (HE), and the histological subtype of samples were classified according to World Health Organization (WHO) classification of 2007, so that only one case was desmoplastic subtype and other cases were classic subtype.

From the histological slides, two representative areas of the tumor were selected and five tissue microarrays (TMAs) were created. Areas non-neoplastic of cerebellum were also included in these TMAs.

Five receptor blocks were cut into five histological sections of $4 \mu \mathrm{m}$ thick. The following antibodies were used: anti-Ki67, mouse monoclonal, dilution 1/100 Dako ${ }^{\circledR}$; anti-TRKC, mouse monoclonal, dilution $1 / 10$ Dako ${ }^{\circledR}$; anti-EGFR, mouse polyclonal, dilution 1:50 Dako ${ }^{\circledR}$; anti-human Bcl-2 oncoprotein Dako ${ }^{\circledR}$ clone 124, dilution 1:200; anti-cyclin D1, mouse monoclonal, dilution $1 / 100$, Dako $^{\circledast}$. The secondary antibody used was AdvanceTM HRP Dako ${ }^{\circledR}$. For the disclosure of slides was added the complex DAB + Dako ${ }^{\circledR}$ substrate on the Star Frost ${ }^{\circledR}$ slides electrically charged, and counterstain was performed with Harris hematoxylin. Entellan ${ }^{\circledR}$ histological resin was used to mount the slides.

The immunohistochemical expression of Ki67, Bcl-2, and cyclin-D1 proteins were evaluated by counting the number of positive tumor cells in a 100 tumor cells count per high power field, it was counted four high power fields for each tumor (two fields in each of the to samples). These counts were compiled, and the average values of each neoplasia now represent the immunohistochemical expression of each protein analyzed by high power field.

In the evaluation of immunohistochemical expression of TRKC and EGFR markers, we used the morphometry of colors of the Image Proplus ${ }^{\circledR}$ application software applicative, in Dell ${ }^{\circledR}$ computer connected to a Dino Eye ${ }^{\circledR}$ camera and to an Olympus BX40 microscope. A normal cerebellum sample was used to standardize the immunohistochemical expression of these two antibodies. In this normal cerebellum sample, an image by high power field $(400 \times)$ was obtained, it showed immunopositive areas for each one of the two antibodies; they were supplied to the software that stored them as a mask. To determine the immunopositive average area per high power field of these two antibodies in medulloblastoma; for each studied case, four images of $40 \times$ objective were obtained. The normal cerebellum image (mask) was superposed over each one of these images using the software, which identifies the areas of color similar to 
the mask, therefore immunopositive, and provides the measure, in square millimeters $\left(\mathrm{mm}^{2}\right)$, of total immunopositive are per high power field.

The following clinical data were obtained from medical records review of 29 patients: age at diagnosis, risk group, type of surgical resection (complete or not), occurrence or not of postoperative tumor recurrence and time for these recurrence, presence or absences of metastases at diagnosis, realization or not of postoperative adjuvant chemotherapy, and occurrence or not of post-treatment deaths, and time for death. The time for this study follow-up ranged from two to thirteen years. Only 29 from 35 cases had suitable records data (six records were not found or could not be found).

The variable normality condition was evaluated by the Kolmogorov-Smirnov test. To evaluate the correlation of two quantitative variables, the Spearman's correlation coefficient was estimated. For the comparison between two groups in relation to the quantitative variables, the nonparametric Mann-Whitney test was used. The $p<0.05$ values indicate statistical significance. Data were analyzed with the Statistica v.8.0 software.

\section{RESULTS}

Considering the 29 studied patients, the average age of patients at diagnosis was 4.8 years, the youngest patient was a month of age and the oldest was 15 years. Twenty patients were at high risk (age under 3 years, presence of residual tumor after surgery and/or presence of metastasis at diagnosis). All patients were subjected to surgical treatment, as recommended by the literature, which 15 of them still had residual lesion after surgery. None of the 29 patients in this study had metastasis at diagnosis. The presence of postoperative recurrence was observed in nine of the 29 patients and the average time for these recurrences was 1.7 years. Twenty-six patients required postoperative chemotherapy. Among the 29 studied patients, three deaths were observed, the average time between the diagnosis and the final outcome was 32.7 days (Table 1).

The average TRKC (Figure) and EGFR immunoexpression in this study was $0.0056 \mathrm{~mm}^{2}$, and $0.0012 \mathrm{~mm}^{2}$, respectively. The average immunoexpression for Ki67, Bcl-2 and cyclin-D1, was $29.9,3.8$ and 2.9 positive nuclei in 100 cells, respectively (Table 1).

The average immunoexpression for Ki67, TRKC, and EGFR were compared to the study clinical variations (age, age group, if older or younger than three years of age, risk group, whether
TABLE 1 - Shows the clinicopathologic variables, risk group and mortality rate of studied patients $(n=29)$ and the immunostaining of evaluated biomarkers $(n=35)$

\begin{tabular}{|c|c|c|}
\hline Clinicopathologic variables & Frequency & Percentage \\
\hline \multicolumn{3}{|c|}{ Age at prognosis $(n=29)$} \\
\hline$<3$ & 10 & 34.5 \\
\hline$\geq 3$ & 19 & 65.5 \\
\hline \multicolumn{3}{|c|}{ Presence of complete resection $(n=29)$} \\
\hline Yes & 14 & 48.3 \\
\hline No & 15 & 51.7 \\
\hline \multicolumn{3}{|c|}{ Presence of postoperative recurrence $(n=29)$} \\
\hline Yes & 9 & 31 \\
\hline No & 20 & 69 \\
\hline \multicolumn{3}{|c|}{ Presence of metastases at diagnosis $(n=29)$} \\
\hline Yes & 0 & 0 \\
\hline No & 29 & 100 \\
\hline \multicolumn{3}{|c|}{ Postoperative chemotherapy $(n=29)$} \\
\hline Yes & 26 & 89.7 \\
\hline No & 3 & 10.3 \\
\hline \multicolumn{3}{|c|}{ Death $(n=29)$} \\
\hline Yes & 3 & 10.3 \\
\hline No & 26 & 89.7 \\
\hline \multicolumn{3}{|c|}{ Risk group $(n=29)$} \\
\hline Low & 9 & 31 \\
\hline High & 20 & 69 \\
\hline Variables & Average (SD) & Median \\
\hline TRKC immunostaining $(n=35)$ & $0.0056(0.0016)$ & 0.0056 \\
\hline EGRF immunostaining $(n=35)$ & $0.0012(0.0007)$ & 0.0011 \\
\hline Ki67 immunostaining $(n=35)$ & $29.9(29.5)$ & 26.2 \\
\hline Age at diagnosis $(n=29)$ & $4.8(3.3)$ & 4.0 \\
\hline Time of postsurgical recurrence $(n=9)$ & $1.7(0.4)$ & 2.0 \\
\hline Time until death $(n=3)$ & $32.7(24.4)$ & 25.0 \\
\hline
\end{tabular}

TRKC and EGFR immunoexpression in square millimeters $\left(\mathrm{mm}^{2}\right)$; Ki67 immunoexpression in number of positive nuclei in 100 nuclei counted in high power field $(H P F=400 \times)$; age at diagnosis and time of postsurgical recurrence in years and time until death in days

SD: Standard deviation; TRKC: neurotrophin-3 receptor; EGFR: epidermal growth factor receptor; HPF: bigh power field.

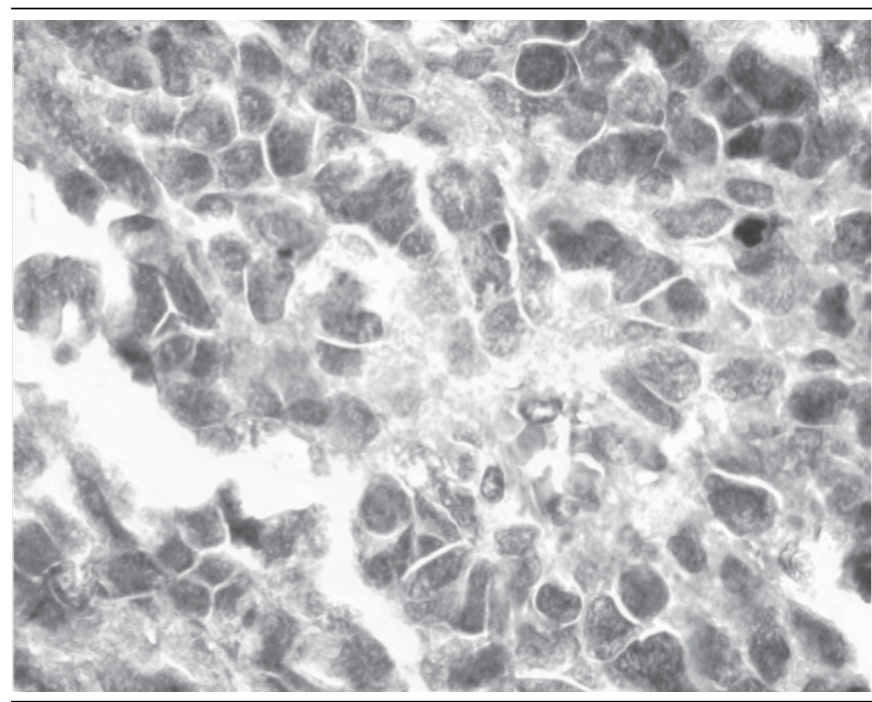

FIGURE - Histological section of pediatric medulloblastoma immunostained with antiTRKC antibody showing strong positivity in the cytoplasm of neoplastic cells (400×) TRKC: receptor neurotrophin-3. 
high or low, presence of complete resection after surgery, presence of postoperative recurrence, presence of postoperative chemotherapy, and occurrence of deaths), data were shown in Tables 2 and 3 . Furthermore, the average immunoexpressions of biomarkers were correlated to each other (Table 3). The older patients showed TRKC higher expression $(p=0.033$ ). There was inversely proportional and statistically significant correlation

TABLE 2 - Shows the correlation between the average immunoexpression of biomarkers and the clinicopathologic variables of studied patients $(n=29)$

\begin{tabular}{|c|c|c|c|c|}
\hline Marker & Clinicopathologic variables & Average (SD) & Median & $p$ values \\
\hline \multicolumn{5}{|c|}{ Total surgical resection $(n=29)$} \\
\hline \multirow[t]{2}{*}{ TRKC } & No & $0.0054(0.0012)$ & 0.0052 & \\
\hline & Yes & $0.0056(0.0012)$ & 0.0059 & 0.905 \\
\hline \multirow[t]{2}{*}{ EGFR } & No & $0.0013(0.0007)$ & 0.0011 & \\
\hline & Yes & $0.0012(0.0008)$ & 0.0009 & 0.458 \\
\hline \multirow[t]{2}{*}{ Ki67 } & No & $32.1(32.7)$ & 43.5 & \\
\hline & Yes & $27.1(25.6)$ & 29.9 & 0.650 \\
\hline \multicolumn{5}{|c|}{ Postsurgical recurrence $(n=29)$} \\
\hline \multirow[t]{2}{*}{ TRKC } & No & $0.0055(0.0012)$ & 0.0052 & \\
\hline & Yes & $0.0056(0.0014)$ & 0.0059 & 0.735 \\
\hline \multirow[t]{2}{*}{ EGFR } & No & $0.0011(0.0007)$ & 0.0009 & \\
\hline & Yes & $0.0015(0.0009)$ & 0.0014 & 0.360 \\
\hline \multirow[t]{2}{*}{ Ki67 } & No & $31.5(31.0)$ & 33.5 & \\
\hline & Yes & $24.8(23.7)$ & 28.0 & 0.775 \\
\hline \multicolumn{5}{|c|}{ Death } \\
\hline \multirow[t]{2}{*}{ TRKC } & No & $0.0055(0.0013)$ & 0.0059 & \\
\hline & Yes & $0.0052(0.0011)$ & 0.0052 & 0.689 \\
\hline \multirow[t]{2}{*}{ EGFR } & No & $0.0012(0.0007)$ & 0.001 & \\
\hline & Yes & $0.0016(0.0013)$ & 0.0009 & 0.743 \\
\hline \multirow[t]{2}{*}{ Ki67 } & No & $27.9(28.1)$ & 29.9 & \\
\hline & Yes & $42.3(36.8)$ & 60.0 & 0.483 \\
\hline \multicolumn{5}{|c|}{ Age at diagnosis $(n=29)$} \\
\hline \multirow[t]{2}{*}{ TRKC } & $<3$ & 0.0051 & 0.0047 & \\
\hline & $\geq 3$ & 0.0057 & 0.0061 & 0.232 \\
\hline \multirow[t]{2}{*}{ EGFR } & $<3$ & 0.0012 & 0.001 & \\
\hline & $\geq 3$ & 0.0013 & 0.001 & 0.820 \\
\hline \multirow[t]{2}{*}{ Ki67 } & $<3$ & 38.6 & 39 & \\
\hline & $\geq 3$ & 24.9 & 19.5 & 0.348 \\
\hline \multicolumn{5}{|c|}{ Risk group $(n=29)$} \\
\hline \multirow[t]{2}{*}{ TRKC } & High & 0.0054 & 0.00495 & \\
\hline & Low & 0.00572 & 0.00609 & 0.607 \\
\hline \multirow[t]{2}{*}{ EGFR } & High & 0.00128 & 0.00104 & \\
\hline & Low & 0.00118 & 0.0008 & 0.381 \\
\hline \multirow[t]{2}{*}{ Ki67 } & High & 30.51 & 36.25 & \\
\hline & Low & 27.48 & 26.2 & 0.831 \\
\hline
\end{tabular}

TRKC and EGFR immunoexpression in square millimeters $\left(\mathrm{mm}^{2}\right)$; Ki67 immunoexpression in number of positive nuclei in 100 nuclei counted in bigh power field $(H P F=400 \times)$

SD: Standard deviation; TRKC: neurotrophin-3 receptor; EGFR: epidermal growth factor receptor; HPF: high power field.
TABLE 3 - Shows the correlation between the average immunoexpression of biomarkers and the age of patients $(n=29)$ at diagnosis, and the correlation of biomarker with each other $(n=35)$

\begin{tabular}{ccc}
\hline Variables & Spearman correlation coefficient & $p$ value \\
\hline Age at diagnosis and TRKC & 0.41 & $\underline{0.033}$ \\
Age at diagnosis and EGFR & 0.07 & 0.737 \\
Age at diagnosis and Ki67 & -0.33 & 0.088 \\
TRKC and EGFR & 0.32 & 0.071 \\
TRKC and Ki67 & -0.38 & $\underline{0.027}$ \\
EGFR and Ki67 & -0.01 & 0.957 \\
\hline
\end{tabular}

TRKC and EGFR immunoexpression in square millimeters $\left(\mathrm{mm}^{2}\right)$; Ki67 immunoexpression in number of positive nuclei in 100 nuclei counted in bigh power field $(H P F=400 \times)$; age at diagnosis in years. Values in bold and underlined are statistically prognostic, and values in italics indicate a trend to statistical significance.

TRKC: neurotrophin-3 receptor; EGFR: epidermal growth factor receptor; HPF: high power field.

between TRKC and Ki67 $(p=0.027)$. These analyses were not performed with Bcl-2 neither cyclin-D1, because only six and four cases were positive for these antibodies, respectively.

\section{DISCUSSION}

The medulloblastoma diagnosis is primarily based on morphological criteria; however, occasionally immunohistochemistry may be used, with anti-synaptophysin antibodies (SYN) and anti-glial fibrillary acidic protein (GFAP). Other prognostic biomarker have been proposed for medulloblastoma, Ki67 proliferative protein has been extensively studied, besides having a correlation with the prognosis of these lesions, since higher proliferative indices seems to be correlated with poor prognosis ${ }^{(0,10,14)}$.

The result analysis showed that older patients had higher expression of TRKC $(p=0.033)$ (Table 3$)$. A higher expression of these biomarkers seems to be associated with a better prognosis, a fact already recorded in the literature, which also considers the age group over three years as at low risk ${ }^{(9)}$. We also observed a statistical trend toward Ki67 is inversely correlated with age $(p=0.088$ ), i.e., the higher the age, the lower proliferative rate. This also seems to be in agreement with the literature, since children over 3 years of age are considered at low risk, and, consequently would have lower proliferative rates and better prognosis (Table 3) ${ }^{(10)}$.

TRKC represents the pathway of growth factors receptors. The main factors found in this group are TRKC, EGFR, platelet derived growth factor receptor (PDGFR), and insulinlike growth factor (IGF) receptor. TRKC, when activated in 
medulloblastoma, stimulate apoptosis. The apoptosis degree is directly proportional to TRKC expression, so, the higher the concentration, the better the prognosis ${ }^{(3,11,12)}$.

The study showed an inversely proportional and statistically significant correlation between TRKC and Ki67 $(p=0.027)$, and the greater the Ki67, the lower the TRKC expression. This seems to be in agreement with literature since TRKC is a biomarker of apoptosis of good prognosis, and Ki67 is biomarker of cellular proliferation and poor prognosis, when presenting high levels ${ }^{(9,10)}$. We also observed a trend $(p=0.071)$ to a directly proportional correlation between TRKC and EGFR, so that when the first is increasing the latter increases also, which seems to be an antagonistic effect, since TRKC stimulate the apoptosis and EGFR promotes cell growth.
The immunohistochemical expression of Ki67 protein is a marker widely used to assess the rate of cell proliferation in tumors. Medulloblastoma are rapidly proliferating tumors of and have high Ki67 expression ${ }^{(1,7)}$. The inverse correlation between Ki67 and TRKC indicate, therefore, a better prognosis.

\section{CONCLUSION}

According to our results and the literature, TRKC might be considered a marker associated to better prognosis tumors, also contributing to stratify patients into risk groups when choosing a treatment.

\section{RESUMO}

Introdução: O meduloblastoma éo tumor maligno do cerebelo com prognóstico reservado. Seu tratamento baseia-se somente em critérios clínicos, como os grupos de risco que levam em consideração apenas idade, extensão de ressecção, recidiva e metástase. Objetivo: Avaliar uma possível relação entre a imunoexpressão de biomarcadores (Ki67, receptor de neurotrofina-3 [TRKC], epidermal growth factor receptor [EGFR], B-cell lymphoma 2 [Bcl-2] e ciclina-D1) e os fatores prognósticos clinicos clássicos dos meduloblastomas. Material e método: Trinta e cinco amostras de meduloblastomas pediátricos livres de tratamento quimioterápico neoadjuvante foram separadas e revisadas quanto a sua classificação histopatológica, sendo duas áreas representativas do tumor utilizadas na construção de arranjos teciduais em matriz. Os seguintes dados clínicos de 29 pacientes foram utilizados para comparação com a expressão dos biomarcadores: idade do paciente, presença ou não de resseç̧ão tumoral completa, estadiamento do paciente em grupo de risco, presença ou não de metástases, presença ou não de tratamento quimioterápico pós-cirúrgico e presença ou não de recidivas. O tempo de seguimento clínico do estudo variou de dois a treze anos, e os casos com desfecho fatal foram também analisados. Resultados: Os pacientes com idade mais elevada apresentaram expressão maior de TRKC $(\mathrm{p}=$ 0,033). Howve correlação inversamente proporcional e estatisticamente significativa entre o TRKC e o Ki67 ( $\mathrm{p}=$ 0,027). Não bouve relevância estatística nas análises do EGFR, Bcl-2 e ciclina-D1. Conclusão: A imunoexpressão do TRKC pode vir a ser considerada um biomarcador relacionado com tumores de melhor prognóstico em pacientes com meduloblastoma, contribuindo para uma melhor estratificação dos grupos de risco.

Unitermos: meduloblastoma; TRKC; Ki67; EGFR; prognóstico; comportamento biológico.

\section{REFERENCES}

1. BHATIA, B. ET AL. Hedgehog-mediated regulation of PPARc controls metabolic patterns in neural precursors and shh-driven medulloblastoma. Acta Neuropathol, v. 123, p. 587-600, 2012.

2. CARLOTTI JR, C. G.; SMITH, C.; RUTKA, J.T. The molecular genetics of medulloblastoma: an assessment of new therapeutic targets. Neurosurg Rev, v. 31, p. 359-69, 2008.
3. DE BONT, J. M. ET AL. Biological background of pediatric medulloblastoma and ependymoma: A review from a translational research perspective. Neuro-Oncology, v. 10, p. 1040-60, 2008.

4. DE HAAS, T. et al. Molecular risk stratification of medulloblastoma patients basedon immunohistochemical analysis of MYC, LDHB, and CCNB1 expression. Clin Cancer Res, v. 14, p. 13-5, 2008.

5. EMMENEGGER, B. A., WECHSLER-REYA, R. J. Stem cells and the origin and propagation of brain tumors. J Child Neurol, v. 23, p. 11725,2008 
6. GROTZER, M. A. et al. Which clinical and biological tumor markers proved predictive in the prospective multicenter trial HIT'91--implications for investigating childhood medulloblastoma. Klin Pediatr, v. 219, p. 312-7, 2007.

7. HARRIS, P. S. ET AL. Polo-like kinase 1 (PLK1) inhibition suppresses cell growth and enhances radiation sensitivity in medulloblastoma cells. BMC Cancer, v. 12, p. 80-5, 2012.

8. HUANG, J. ET AL. Mutations in the Nijmegen Breakage syndrome gene in medulloblastomas. Clin Cancer Res, v. 14, n. 13, p. 4053-7, 2008.

9. KIM, J. Y. et al. Activation of neurotrophin-3 receptor TrkC induces apoptosis in medulloblastomas. Cancer Res, v. 59, p. 711-9, 1999.

10. MEURER, R. T. ET AL. Immunohistochemical expression of markers ki-67, neun, synaptophysIn, p53 and her2 in medulloblastoma and its correlation with clinicopathological parameters. Arq Neuropsiquiatr, v. 66, n. 2B, p. 385-90, 2008.
11. PACKER, R. J.; MACDONALD, T.; VEZINA, G. Central nervous system tumors. Hematol Oncol Clin NAm, v. 24, p. 87-108, 2010.

12. ROSSI, A. et al. Medulloblastoma: from molecular pathology to therapy. Clin Cancer Res, v. 14, p. 4-7, 2008.

13. RUTKOWSKI, S. et al. Prognostic relevance of clinicaland biological risk factors in childhood medulloblastoma: results of patients treated in the prospective multicenter trial HIT'91. Clin Cancer Res, v. 13, p. 9-11, 2007.

14. SAMKARI, A.; HWANG, E.; PACKER, R. J. Medulloblastoma/primitive neuroectodermal tumor and germ cell tumors. Hematol Oncol Clin $N$ Am, v. 26, p. 881-95, 2012.

15. SHIM, K.W. et al. Prediction of prognosis in children with medulloblastoma by using immunohistochemical analysis and tissue microarray.J Neurosurg Pediatr, v. 1, p. 196-205, 2008. 